\title{
Does Social Insurance Block the Inter-Generational Transmission of Poverty? Evidence from the 2018 China Family Panel Survey
}

\author{
Xianhua Dai ${ }^{1,2, *(D)}$ and Nian $\mathbf{G u}^{1}$ \\ 1 School of Public Administration, Central China Normal University, Wuhan 430079, China; \\ gn1684168437@163.com \\ 2 Center for Labor and Social Security Research, Central China Normal University, Wuhan 430079, China \\ * Correspondence: xhdai@ccnu.edu.cn
}

check for updates

Citation: Dai, X.; Gu, N. Does Social Insurance Block the Inter-Generational Transmission of Poverty? Evidence from the 2018

China Family Panel Survey.

Sustainability 2022, 14, 750.

https://doi.org/10.3390/su14020750

Academic Editors: Srinivas Goli,

Bidhubhusan Mahapatra and

Tushar Bharati

Received: 9 December 2021

Accepted: 8 January 2022

Published: 11 January 2022

Publisher's Note: MDPI stays neutral with regard to jurisdictional claims in published maps and institutional affiliations.

Copyright: (c) 2022 by the authors. Licensee MDPI, Basel, Switzerland. This article is an open access article distributed under the terms and conditions of the Creative Commons Attribution (CC BY) license (https:// creativecommons.org/licenses/by/ $4.0 /)$.

\begin{abstract}
In this research, we explored whether participation in pension insurance and medical insurance for children and fathers blocks the inter-generational transmission of poverty. Using data from the China Family Panel Survey of 2018, this paper took the average level of insurance participation of a sample group as an instrumental variable, applied the IV-probit model, and found that the participation of children in pension insurance and the participation of fathers in medical insurance significantly reduce the probability of the inter-generational transmission of poverty, but that the participation of children in medical insurance and the participation of fathers in pension insurance increase it. These results were robust. Furthermore, there was heterogeneity in household registration, geographical location, and marriage with regard to the impact of social insurance participation on the inter-generational transmission of poverty. These results could help the formulation of anti-poverty policies to address the inter-generational transmission of poverty.
\end{abstract}

Keywords: social insurance; inter-generational transmission of poverty; instrumental variable; IV-probit model

\section{Introduction}

Blocking the inter-generational transmission of poverty (ITP) is an important antipoverty strategy. China must lift the whole territory out of absolute poverty. As an important economic and social issue, poverty alleviation is affected by complex factors $[1,2]$, such as the habits and social capital of individuals [3-5], family economic status and the living environment [6], and emergencies like COVID-19 [7], and it also persists within families [8].

Proposed in the 1960s, the inter-generational transmission of poverty refers to a vicious genetic chain in which poverty, related conditions, and factors are transmitted from parent to child within a family, so that the child inherits his/her parents' poverty and adverse factors in adulthood $[9,10]$. Most of the existing literature measured ITP using inter-generational income elasticity, and explored the blocking effect of specific factors on ITP [11-13]. Some literature used a transformation matrix to measure ITP [14-16]. The latter directly measured the occurrence and transmission of poverty, and conveniently explored the influencing factors and mechanisms. This paper applied the transfer matrix. As shown by the transitive nature of ITP, the occurrence of poverty between parents and children is sequential. To reduce sample selection bias, this paper concentrated on the father-child pair where the father was poor, due to the following consideration: firstly, in the changes of family structure, most fathers always assumed the role of family authority and major economic contributors [17], which had an important impact on children's growth and development. Secondly, in the matched data, we found that there was a serious lack 
of relevant information about mothers. To reduce the loss of information, we mainly concentrated on the transmission of poverty between fathers and children.

This paper contributes to the measurement of individual poverty. At present, in most literature poverty is mainly defined as income below a certain level; thus, the key to measuring poverty lies in the measurement of income and the poverty line. An individual's weekly, monthly, and annual work earnings are the most common measurements of income [18-21]. Average income over a specific survey period, for example, years or survey waves, is also used to measure individual income [22,23]. Work earnings may be the main source of individual income, but not all it comes from them, especially for individuals whose income mainly comes from operations and investments. This paper integrates person and family databases and measures individual income by considering four aspects: work income, business income, property income, and transfer income. In addition, there are many poverty lines; for example, the absolute poverty lines of $\$ 1.9$ per person per day [24], $¥ 2300$ every year for the agricultural population, as proposed in 2011 , and $¥ 3200$ per year, as proposed in 2018. However, as China's anti-poverty strategy is entering a new stage, focusing on the relative poverty line is reasonable. Generally, the relative poverty line includes $50 \%$ or $70 \%$ of the median of per capita disposable income $[25,26]$, and the average of per capita disposable income $[27,28]$. This paper used the former as the relative poverty line, since the median better represents the income of most residents.

This paper also contributes to the understanding of the impact of social insurance on the inter-generational transmission of poverty. The existing literature on the ITP explores blocking methods [29-31]. Childhood living conditions are important, since the poverty of the father may lead to deficiencies in the nutrition and living environments of children, who may then fall into poverty due to health problems in adulthood [32,33]. Education and culture are other important pathways; a father's poor education may lead to his child's inability to receive a good education, resulting in multidimensional poverty in the sense of low income and spirit $[3,16,34]$. Social capital is another important perspective. Poor parents accumulate less social capital and provide less help to their children in life, work, and communication, resulting in an increase in the probability of their children inheriting poverty [4]. This literature contributes to the current understanding of the blocking of the transmission of poverty, but also takes into account the rarely touched upon impact of social insurance. As an important social policy, social security is important in poverty alleviation [22,35-38]. For example, the significant but limited public pension plans for some elderly people [39-41] and medical insurance significantly decreases the probability of poverty due to illness [42-47]. However, the literature seems to have largely ignored the impact of social insurance on the inter-generational transmission of poverty. This paper explores the impact of the participation of fathers and children in pension insurance and medical insurance on the ITP.

Applying instrumental variables and the IV-probit model, we found that social insurance has varying significant impacts on the inter-generational transmission of poverty. In particular, child participation in pension insurance and fathers' participation in medical insurance significantly reduce the probability of ITP, but child participation in medical insurance and fathers' participation in pension insurance have the opposite effect. In particular, child education, political identity, behavior, and family characteristics have significant impacts on probability of the ITP. These results were robust. Furthermore, the impact of social insurance participation on the ITP is heterogeneous in terms of the residence and marriage status of the child.

The paper is arranged as follows. Section 2 presents the data, variables, and summary statistics. Section 3 outlines the empirical approach. Section 4 demonstrates the results of the basic analysis, robustness check, and heterogeneity analysis. Section 5 provides the conclusion and discussion. 


\section{Data, Variables, and Summary Statistics}

\subsection{Data}

The data used in this paper came from the China Family Panel Studies (CFPS), carried out by the China Social Science Investigation Center at Peking University. The CFPS is an ongoing longitudinal survey which started in 2010. The data are collected by interview once every two years, based on a permanent sample of 14,960 households and 42,590 individuals who entered the 2010 baseline survey. It is a detailed and comprehensive investigation into family income, social insurance participation, education, health, and individual characteristics. In addition, it has a large sample capacity, wide coverage, reasonable questionnaire design, scientific survey methods, and timely data updates, which effectively reflect the development of our society.

This paper concentrated on the impact of social insurance on the intergenerational transmission of poverty. We started with 32,669 respondents from the CFPS sample in 2018. Firstly, we matched the information for children and fathers according to the family relationship database, and deleted samples that could not be matched successfully. Secondly, samples with missing information on any item were deleted. Thirdly, individuals under 17 years old and over 65 years old were deleted. Finally, samples with an income of 0 or no income, due to the participants being in school or out of the labor market, were deleted. After the above data screening, we obtained 2099 pairs of valid samples.

The key variables are defined in the following subsections.

\subsection{Variables}

\subsubsection{Intergenerational Transmission of Poverty (ITP)}

This paper used the incomes of the child and father as the measurement of poverty. First, we summarized the working income, operating income, property income, and transfer income of both the child and the father. Then, we considered $50 \%$ of the median of the national per capita disposable income in 2017 as the relative poverty line to measure individual poverty. Finally, we retained the sample pairs in which the father was in poverty, and recorded 1 if the child was also poor, and 0 otherwise.

\subsubsection{Social Insurance (SI)}

As China is establishing a multi-level social insurance system, the social insurance discussed in this paper includes basic social insurance and supplementary social insurance. This paper concentrated on pension insurance and medical insurance, recording 0 if the individual had neither basic social insurance nor supplementary social insurance, 1 if they had one of them, and 2 if they had both of them.

\subsubsection{Other Explanatory Variables}

We also focused on other exogenous variables that may affect poverty or social insurance participation. Personal characteristics, including gender, age, household registration, education, health status, job type, and geographical location. It should be noted that since Chinese pension insurance and medical insurance have two types, namely employee insurance and resident insurance, and the urban and eastern regions have had an earlier and greater implementation of the insurance policy, higher payment, and treatment levels than rural and other geographical regions, we took household registration, job type, and geographical location into consideration. The social capital of parents and individuals can be transformed into human capital and economic capital, and so may have an impact on the transmission of poverty. Therefore, we also considered the social position and political identity of children and parents, and the expenditure of families for gifting. For the latter, since in Chinese culture gifting is an important part of maintaining social networks, we believed that it was reasonable and necessary to include it as a proxy variable. Behavior, smoking, drinking, reading, and exercising may have impacts on social communication and information acquisition, etc., so they were regarded as part of the control variables. In addition, we considered the characteristics of the family, such as size and factors that can 
reflect and affect the family's economic situation, in particular, transfer income acquisition, cooking water, and fuel.

Table 1 provides summary statistics for the variables.

Table 1. Descriptive statistics.

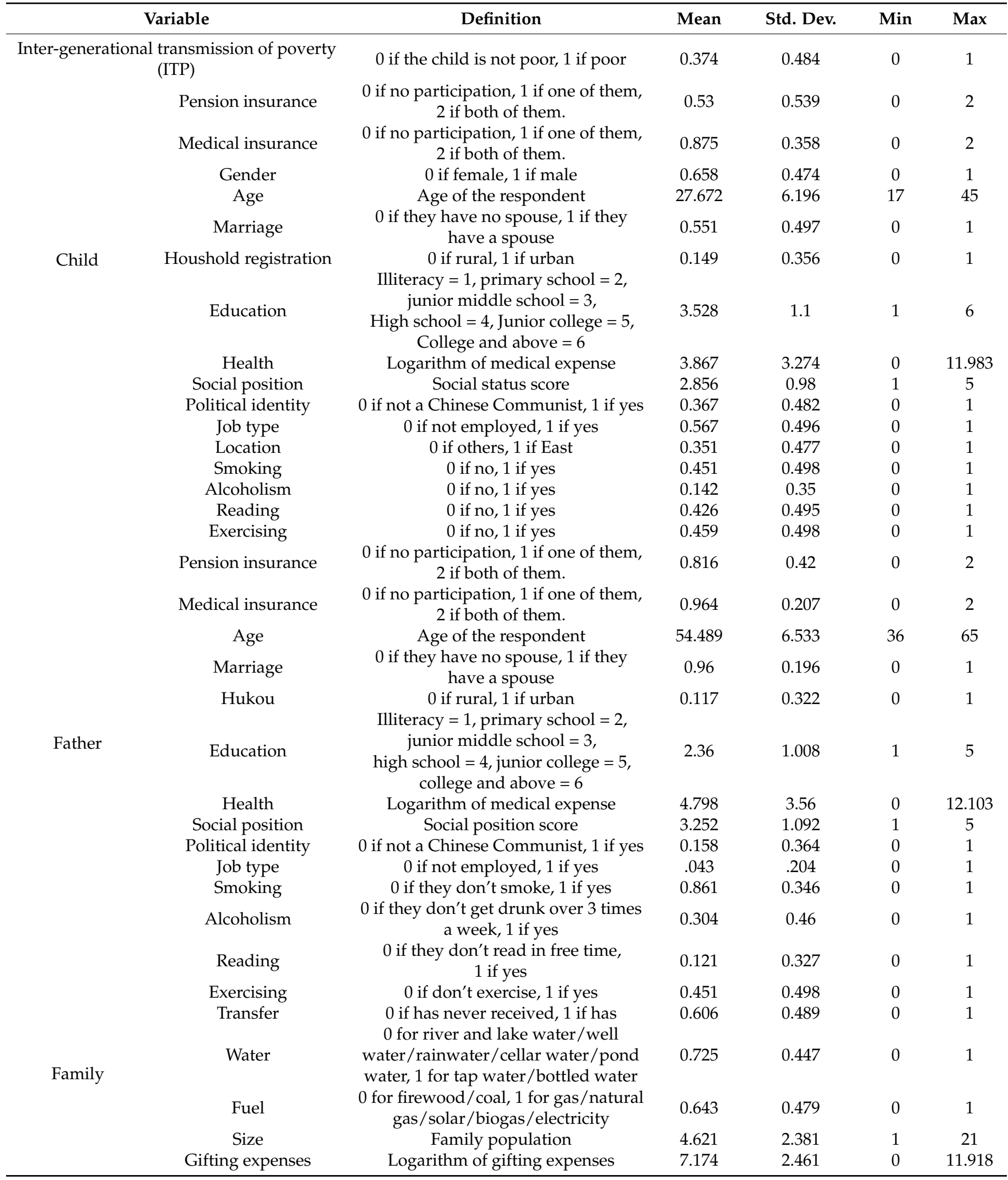




\section{Empirical Approach}

Following the previous literature, the ITP was considered a binary variable, and this paper used the following probit model:

$$
\operatorname{Prob}\left(\mathrm{Y}_{\mathrm{i}}=1 \mid \mathrm{X}_{\mathrm{i}}\right)=\operatorname{Prob}\left(\sum_{\mathrm{j}=1}^{4} \alpha_{\mathrm{j}} \mathrm{SI}_{\mathrm{ji}}+\sum_{\mathrm{k}=1}^{12} \beta_{\mathrm{k}} \text { Child }_{\mathrm{ki}} \beta_{\mathrm{k}}+\sum_{\mathrm{m}=1}^{11} \gamma_{\mathrm{m}} \text { Father }_{\mathrm{mi}}+\sum_{\mathrm{n}=1}^{5} \theta_{\mathrm{n}} \text { Family }_{\mathrm{ni}}+\varepsilon_{\mathrm{i}} \mid \mathrm{X}_{\mathrm{i}}\right)
$$

where $Y_{i}$ is the occurrence of inter-generational transmission of poverty in child $i$, which is a dummy variable and scored 1 if there is an ITP and 0 otherwise. $\mathrm{SI}_{\mathrm{ji}}$ is participation in $j$-th social insurance (pension insurance and medical insurance) of child $i$ and his (her) father. Child $\mathrm{ki}_{i}$ is the k-th characteristics of child i, Father ${ }_{\mathrm{mi}}$ is the m-th father's characteristics of child $\mathrm{i}$, Family $\mathrm{ni}_{\mathrm{i}}$ is the $\mathrm{n}$-th family characteristics of child, and $\varepsilon_{\mathrm{i}}$ is an error term.

For this model, there may be endogeneity due to reverse causality. Participating in social insurance can reduce the impact of accidents on personal and family income. Chinese urban-rural residents insurance and supplementary insurance are voluntary, and employee insurance takes personal income as the payment base, so individuals with lower incomes tend not to participate in social insurance. To solve this problem, we used the instrumental variable (IV) and IV-probit. We took the average participation rate of the group as the instrumental variable of social insurance participation. Specifically, we divided all the samples into 60 groups according to the provinces and classification of urban and rural areas where the children were located, and three groups with small sample sizes were excluded. Then, we calculated the average participation level of pension insurance and medical insurance of the children and parents in each group. In general, the IV is valid if it meets several assumptions below.

Exclusion restriction assumption: relevance and exogeneity. The average area participation level of social insurance is affected by policies and the operation of insurance funds. In poor areas, the government provides the lowest level of social insurance for poor groups free of charge in order to deal with poverty, which suggests that the average participation level can only further affect the ITP by affecting individual participation in SI.

Relevance assumption: the average participation level at the cluster level has a strong correlation with individual participation. This is fulfilled since the generation shows the direct relationship between individual participation in SI and the instrumental variables. In order to make the IV estimation more reliable, we carried out a weak instrumental variable test in the IV-probit model, and as shown in the result in Section 4.1, the assumption is fulfilled.

Monotonicity assumption: whereas participation in SI is certain if the individual lives in an area with a high average participation level, non-participation is certain if they live in an area with a low average participation level. On the one hand, the average participation level is generated based on individual participation. Therefore, individuals living in areas with a higher/lower average participation level have a greater probability of participating in SI. On the other hand, an area with higher average participation is more likely to have better cultural, economic, and social foundation conditions to promote the policy, and vice versa. Therefore, the IV fulfills the assumption.

We also carried out a robustness check for the conclusions. Specifically, we added the children's cognition and attitude to life into the model, used alternative samples and alternative methods for analysis, and found that the conclusions were robust.

In order to further address whether there were group differences in the impact of SI on the ITP, we conducted heterogeneity analysis in household registration, geographical location, and marital status. As shown, there is group heterogeneity in the conclusions.

\section{Results}

\subsection{Basic Regression}

The collinearity test indicated there was no collinearity problem in the model. See Table A1 for the results of the test. 
Table 2 presents the results for probit and IV-probit models on the effects of SI on the ITP. As shown by the probit model in column 2, at the level of $1 \%$, child participation in pension insurance $(-0.277)$ significantly reduced the probability of the ITP. At the level of $10 \%$, child participation in medical insurance $(0.172)$ and fathers' participation in pension insurance (0.149) and medical insurance (0.301) significantly increased the probability of the ITP. However, as previously analyzed, endogeneity may lead to the regression error, so we payed more attention to the results of IV probit. As shown by the IV-probit model in column 3, which differs from the probit model, child participation in pension insurance $(-0.839)$ and father's participation in medical insurance $(-2.342)$ statistically significantly decreases the probability of the ITP, while child participation in medical insurance (1.228) and fathers' participation in pension insurance (1.228) had significant impacts on the probability of the ITP at the significance of $1 \%$ level.

Table 2. Basic Regression.

\begin{tabular}{|c|c|c|}
\hline \multirow{2}{*}{ Variables } & (1) & (2) \\
\hline & Probit & IV-Probit \\
\hline Child's Pension Insurance & $\begin{array}{l}-0.277^{* * * *} \\
(0.064)\end{array}$ & $\begin{array}{l}-0.839^{* * * *} \\
(0.288)\end{array}$ \\
\hline Child's Medical Insurance & $\begin{array}{l}0.172 * \\
(0.089)\end{array}$ & $\begin{array}{l}1.228^{* * *} \\
(0.464)\end{array}$ \\
\hline Father's Pension Insurance & $\begin{array}{c}0.149 * * \\
(0.076)\end{array}$ & $\begin{array}{c}0.719 * * * \\
(0.265)\end{array}$ \\
\hline Father's Medical Insurance & $\begin{array}{l}0.301 * \\
(0.159)\end{array}$ & $\begin{array}{l}-2.342^{* * *} \\
(0.663)\end{array}$ \\
\hline $\begin{array}{c}\text { Gender } \\
\text { (Reference: Female) }\end{array}$ & $\begin{array}{l}-0.126 \\
(0.083)\end{array}$ & $\begin{array}{l}-0.070 \\
(0.079)\end{array}$ \\
\hline Child's Age & $\begin{array}{l}-0.039 * * * \\
(0.009)\end{array}$ & $\begin{array}{l}-0.018 \\
(0.013)\end{array}$ \\
\hline $\begin{array}{c}\text { Child's Marriage } \\
\text { (Reference: Unmarried) }\end{array}$ & $\begin{array}{c}-0.071^{* * *} \\
(0.082)\end{array}$ & $\begin{array}{l}-0.005 \\
(0.090)\end{array}$ \\
\hline $\begin{array}{l}\text { Child's Household } \\
\text { Registration }\end{array}$ & -0.023 & 0.144 \\
\hline (Reference:Rural) & $(0.120)$ & $(0.116)$ \\
\hline Child's Education & $\begin{array}{l}-0.369 \\
(0.037)\end{array}$ & $\begin{aligned}- & 0.235^{* * *} \\
& (0.067)\end{aligned}$ \\
\hline Child's Health & $\begin{array}{l}-0.018^{*} \\
(0.009)\end{array}$ & $\begin{array}{l}-0.010 \\
(0.010)\end{array}$ \\
\hline Child's Social Position & $\begin{array}{l}0.063 * * \\
(0.031)\end{array}$ & $\begin{array}{c}0.038 \\
(0.029)\end{array}$ \\
\hline Child's Political Identity & $0.254^{* * *}$ & $0.169^{* *}$ \\
\hline (Reference: Non-Communist) & $(0.074)$ & $(0.080)$ \\
\hline Child' Job Type & $0.114^{*}$ & $0.120^{* *}$ \\
\hline (Reference: Non-employment) & $(0.061)$ & $(0.058)$ \\
\hline Location & 0.042 & -0.002 \\
\hline (Reference: Non-Eastern) & $(0.069)$ & $(0.065)$ \\
\hline Child's Smoking & $-0.200^{* *}$ & $-0.147^{* *}$ \\
\hline (Reference: Don't smoke) & $(0.080)$ & $(0.075)$ \\
\hline Child's Alcoholism & -0.081 & -0.121 \\
\hline (Reference: No alcoholism) & $(0.092)$ & $(0.084)$ \\
\hline Child's Reading & 0.094 & 0.008 \\
\hline (Reference: No reading) & $(0.067)$ & $(0.063)$ \\
\hline Child's Exercising & $0.157^{* *}$ & $0.132 * *$ \\
\hline (Reference: Don't exercise) & $(0.064)$ & $(0.062)$ \\
\hline Father's Age & $\begin{array}{c}0.006 \\
(0.007)\end{array}$ & $\begin{array}{c}0.000 \\
(0.007)\end{array}$ \\
\hline
\end{tabular}


Table 2. Cont.

\begin{tabular}{|c|c|c|}
\hline \multirow{2}{*}{ Variables } & (1) & (2) \\
\hline & Probit & IV-Probit \\
\hline Father's Marriage & -0.087 & -0.027 \\
\hline (Reference: Unmarried) & $(0.155)$ & $(0.143)$ \\
\hline Father's Household & $0.298^{* *}$ & 0.093 \\
\hline $\begin{array}{l}\text { Registration } \\
\text { (Reference: Rural) }\end{array}$ & $(0.124)$ & $(0.126)$ \\
\hline Father's Education & -0.005 & -0.008 \\
\hline & $(0.034)$ & $(0.031)$ \\
\hline Father's Health & 0.003 & -0.004 \\
\hline & $(0.009)$ & $(0.008)$ \\
\hline Father's Social Position & -0.014 & -0.003 \\
\hline & $(0.028)$ & $(0.026)$ \\
\hline Father's Political Identity & -0.034 & 0.010 \\
\hline (Reference: Non-Communist) & $(0.086)$ & $(0.082)$ \\
\hline Father's Job Type & $-0.288^{*}$ & $-0.303^{* *}$ \\
\hline (Reference: Non-employment) & $(0.153)$ & $(0.137)$ \\
\hline Father's Smoking & 0.041 & 0.062 \\
\hline (Reference: Don't smoke) & $(0.089)$ & $(0.083)$ \\
\hline Father's Alcoholism & 0.086 & 0.079 \\
\hline (Reference: No alcoholism) & $(0.067)$ & $(0.062)$ \\
\hline Father's Reading & 0.014 & 0.041 \\
\hline (Reference: No reading) & $(0.097)$ & $(0.092)$ \\
\hline Father's Exercising & 0.019 & 0.036 \\
\hline (Reference: Don't exercise) & $(0.063)$ & $(0.059)$ \\
\hline Transfer & 0.222 & $0.184^{* * *}$ \\
\hline $\begin{array}{l}\text { (Reference: No transfer } \\
\text { income) }\end{array}$ & $(0.068)$ & $(0.064)$ \\
\hline Water & -0.095 & -0.090 \\
\hline (Reference: Non clean water) & $(0.070)$ & $(0.066)$ \\
\hline Fuel & $-0.170^{* *}$ & -0.057 \\
\hline (Reference: Non clean energy) & $(0.070)$ & $(0.069)$ \\
\hline Size & $0.097^{* * *}$ & $0.054^{* * *}$ \\
\hline & $(0.015)$ & $(0.019)$ \\
\hline Gifting expenses & $0.041^{* * *}$ & $0.030 * *$ \\
\hline & $(0.013)$ & $(0.013)$ \\
\hline Constant & 0.447 & $1.449 *$ \\
\hline & $(0.417)$ & $(0.800)$ \\
\hline Accuracy & 72.08 & 73.28 \\
\hline LR/Wald Chi2 & $441.63^{* * *}$ & $701.17^{* * *}$ \\
\hline Endog & & $31.66^{* * *}$ \\
\hline AR & & $17.50 * * *$ \\
\hline $\mathrm{N}$ & 2099 & 2081 \\
\hline $\mathrm{R}^{2}$ & 0.159 & \\
\hline
\end{tabular}

Note: Based on CFPS 2018. Standard errors in parentheses under the coefficients. ${ }^{*} p<0.1,{ }^{* *} p<0.05,{ }^{* * *} p<0.01$ Reference group in parentheses under the qualitative variable name.

It is very interesting that the participation of children and fathers in pension insurance and medical insurance has opposite effects on the ITP. One possible reason for this is that most children remain in the payment stage and do not obtain income, but their participation still helps them develop an awareness of saving to deal with risks. However, for fathers, pension insurance expenditure reduces their ability to support the family, which may improve the probability of the ITP. The different effects of medical insurance are more likely to be related to the health status of fathers and children. The health status of children is generally better than that of their fathers, as reflected in the descriptive statistics. Therefore, children pay medical insurance but rarely benefit from it, whereas fathers' participation in medical insurance reduces their medical costs and maintains human capital, so it has the opposite effect. 
In addition, child education (-0.235) significantly reduces the probability of the ITP, which verified the economic return of education. A child's job type (0.120) increases the probability of the ITP, while a father's job type $(-0.303)$ has the opposite impact. One possible reason for this is that children are engaged in basic work and fathers are more likely to work in higher paid jobs. A noteworthy phenomenon is that a child's political identity (0.169) significantly improves the probability of the ITP, and, even though it is not significant, the impact of a father's political identity on the ITP it is also positive. This may be due to the fact that most Communist Party members are public servants and receive more physical security, and there is a certain amount of error involved in taking wage level as the measurement for poverty. Moreover, child smoking $(-0.147)$ significantly blocks the ITP while exercising (0.132) increases it. A family's receipt of transfer income (0.184), family size (0.054), and family's gifting expenses (0.03) also have statistically significant impacts on the ITP at different significance levels (see Table 2 for details); thus, short-term income improvement plans for families may not eliminate poverty, but are prone to welfare traps and increase the probability of the ITP. SI is therefore not the only factor affecting the ITP and it is reasonable and necessary to include these variables in the regression model.

The prediction accuracy of probit model and IV-probit model is more than $70 \%$. The chi square value of LR (for the probit model) and Wald (for IV-probit model) is significant, which proves the great quality of the models. Furthermore, using the Wald test for endogeneity, we rejected the null hypothesis of the exogeneity of the participation of children and fathers in pension and medical insurance at the significance level of $1 \%$, so it is reasonable to use the IV-probit model to correct the estimation error from endogeneity. We also carried out a weak-IV test. As shown by the significant AR value, the instrumental variables selected in this paper were effective.

Overall, as shown in Table 2, the participation of children and fathers in social insurance has a statistically significant impact on the ITP.

\subsection{Robustness Check}

\subsubsection{Adding Variables}

Based on the complexity of the ITP, the previous conclusions may be affected by missing variables, so in this section we carried out a robustness check by adding explanatory variables. Specifically, we took into account the respondents' cognitive ability and attitude to life. The variable Cognition was defined by the sum of respondents' phrase and math test scores, and, to measure the respondents' attitude to life, the variable Confidence was measured by the question "How confident are you in the future?", with answers ranging from 1 (worst) to 5 (best). Both of these variables may affect children's economic ability, i.e., the ITP.

As shown in Column 3 of Table 3, after a child's cognition and confidence were added to the model, the coefficients of a child's participation in pension insurance and medical insurance on the ITP increased from -0.839 to -0.842 (pension insurance) and 1.228 to 1.243 (medical insurance), respectively, while on the contrary, the coefficients of a father's participation in pension insurance and medical insurance on the ITP decreased from 0.719 and -2.342 to 0.713 and -2.324 , respectively. So, the impact of SI on the ITP may be more affected by a child's personal characteristics and efforts.

In addition, as the IV-probit results show, a child's education (-0.235), smoking $(-0.147)$ behavior, and their father's employment $(-0.303)$ has significant impacts on blocking the ITP. Meanwhile, a child's Communist identity (0.169), employment (0.12), exercising behavior (0.132), family size expansion (0.054), and gifting expenditure growth (0.03) significantly improves the probability of the ITP. But when the child's confidence enhanced, the probability of the ITP is significantly reduced, hence this check is reasonable.

Overall, in this section, we added explanatory variables to the basic model and found that a child's and a father's participation in SI, and other factors such as child education, political identity, behavior, and family characteristics, have significant impacts on the probability of the ITP. Therefore, the previous conclusions were robust. 
Table 3. Added variables.

\begin{tabular}{|c|c|c|}
\hline \multirow{2}{*}{ Variables } & (1) & (2) \\
\hline & Probit & IV-Probit \\
\hline Child's Pension Insurance & $\begin{aligned}-0.276^{* * *} & (0.064)\end{aligned}$ & $\begin{aligned}- & 0.842^{* * *} \\
& (0.293)\end{aligned}$ \\
\hline Child's Medical Insurance & $\begin{array}{c}0.176^{* *} \\
(0.090)\end{array}$ & $\begin{array}{l}1.243^{* * *} \\
(0.463)\end{array}$ \\
\hline Father's Pension Insurance & $\begin{array}{c}0.154^{* *} \\
(0.076)\end{array}$ & $\begin{array}{l}0.713^{* * *} \\
(0.265)\end{array}$ \\
\hline Father's medical Insurance & $\begin{array}{c}0.296^{* * *} \\
(0.159)\end{array}$ & $\begin{array}{l}-2.324^{* * *} \\
(0.668)\end{array}$ \\
\hline Child's Age & $\begin{array}{l}-0.039^{* * *} \\
(0.009)\end{array}$ & $\begin{array}{l}-0.018 \\
(0.013)\end{array}$ \\
\hline Child's Education & $\begin{aligned} &-0.373 * * * \\
&(0.037)\end{aligned}$ & $\begin{aligned}-0.239^{* * *} & (0.068)\end{aligned}$ \\
\hline Child's Health & $\begin{array}{l}-0.019^{* *} \\
(0.010)\end{array}$ & $\begin{array}{l}-0.011 \\
(0.010)\end{array}$ \\
\hline Child's Social Position & $\begin{array}{c}0.082 * * \\
(0.032)\end{array}$ & $\begin{array}{l}0.053 * \\
(0.030)\end{array}$ \\
\hline Child's Political Identity & $0.253^{* * *}$ & $0.168^{* *}$ \\
\hline (Reference: Non-Communist) & $(0.074)$ & $(0.080)$ \\
\hline Child's Job Type & $0.120 *$ & $0.125^{* *}$ \\
\hline (Reference: Non-employment) & $(0.062)$ & $(0.058)$ \\
\hline Child's Smoking & $-0.191^{* *}$ & $-0.140^{*}$ \\
\hline (Reference: Don't smoke) & $(0.081)$ & $(0.075)$ \\
\hline Child's Exercising & $0.170^{* * *}$ & $0.143^{* *}$ \\
\hline (Reference: Don't exercise) & $(0.065)$ & $(0.063)$ \\
\hline $\begin{array}{c}\text { Father's Household } \\
\text { Registration }\end{array}$ & $0.290 * *$ & 0.085 \\
\hline (Reference: Rural) & $(0.124)$ & $(0.126)$ \\
\hline Father's Job Type & $-0.272 *$ & $-0.283^{* *}$ \\
\hline (Reference: Non-employment) & $(0.153)$ & $(0.138)$ \\
\hline Transfer & $0.217^{* * *}$ & $0.181^{* * *}$ \\
\hline $\begin{array}{l}\text { (Reference: No transfer } \\
\text { income) }\end{array}$ & $(0.068)$ & $(0.064)$ \\
\hline Fuel & $-0.172 * *$ & -0.059 \\
\hline (Reference: Non clean energy) & $(0.070)$ & $(0.069)$ \\
\hline Size & $\begin{array}{c}0.097 * * * \\
(0.015)\end{array}$ & $\begin{array}{c}0.054^{* * *} \\
(0.019)\end{array}$ \\
\hline Gifting expenses & $\begin{array}{c}0.041^{* * *} \\
(0.013)\end{array}$ & $\begin{array}{l}0.030^{* *} \\
(0.013)\end{array}$ \\
\hline Child's Confidence & $\begin{array}{l}-0.072 * * \\
(0.037)\end{array}$ & $\begin{array}{l}-0.062 * \\
(0.035)\end{array}$ \\
\hline Child's Cognition & $\begin{array}{c}0.006 \\
(0.010)\end{array}$ & $\begin{array}{c}0.007 \\
(0.009)\end{array}$ \\
\hline Constant & $\begin{array}{c}0.695 \\
(0.448)\end{array}$ & $\begin{array}{l}1.626^{* *} \\
(0.815)\end{array}$ \\
\hline Accuracy & 72.15 & 73.11 \\
\hline LR/Wald Chi2 & 445.17 & $704.69^{* * *}$ \\
\hline Endog & & $31.12^{* * *}$ \\
\hline $\mathrm{AR}$ & & $17.33^{* * *}$ \\
\hline $\mathrm{N}$ & 2097 & 2079 \\
\hline $\mathrm{R}^{2}$ & 0.161 & \\
\hline
\end{tabular}

Note: Based on CFPS 2018. Standard errors in parentheses under the coefficients. ${ }^{*} p<0.1{ }^{* *} p<0.05,{ }^{* * *} p<0.01$. Reference group in parentheses under the qualitative variable name. Insignificant variables are omitted.

\subsubsection{Alternative Sample}

Unlike medical insurance, pension insurance can only be received under certain conditions. This paper focused on the impact of the payment of pension insurance on the 
probability of the ITP. We retained a sample of 1705 children whose parents had not yet received a pension to carry out the robustness check.

As shown in Table 4, in the probit model, only child participation in medical insurance has no significant impact on ITP. But in the IV-probit model, a child's participation in pension insurance $(-0.653)$ and a father's participation in medical insurance $(-2.139)$ have significant blocking effects on the ITP, while a child's participation in medical insurance (0.947) and a father's participation in pension insurance (0.683) have significant opposite effects. This is consistent with the conclusions of the basic regression model, so the impact of child and father participation in SI on the ITP are robust.

Table 4. Alternative samples.

\begin{tabular}{|c|c|c|}
\hline \multirow{2}{*}{ Variables } & (1) & (2) \\
\hline & Probit & IV-Probit \\
\hline Child's Pension Insurance & $\begin{array}{c}-0.252 * * * \\
(0.072)\end{array}$ & $\begin{array}{c}-0.652 \text { * } \\
(0.391)\end{array}$ \\
\hline Child's Medical Insurance & $\begin{array}{c}0.155 \\
(0.096)\end{array}$ & $\begin{array}{l}0.947^{*} \\
(0.529)\end{array}$ \\
\hline Father's Pension Insurance & $\begin{array}{c}0.169^{* *} \\
(0.079)\end{array}$ & $\begin{array}{c}0.683^{* *} \\
(0.309)\end{array}$ \\
\hline Father's Medical Insurance & $\begin{array}{c}0.248^{* * *} \\
(0.175)\end{array}$ & $\begin{array}{c}-2.139 * * * \\
(0.692)\end{array}$ \\
\hline Child's Age & $\begin{array}{c}-0.048^{* * *} \\
(0.011)\end{array}$ & $\begin{array}{c}-0.032 \text { * } \\
(0.017)\end{array}$ \\
\hline Child's Education & $\begin{array}{c}-0.385^{* * *} \\
(0.042)\end{array}$ & $\begin{array}{c}-0.285^{* * *} \\
(0.081)\end{array}$ \\
\hline Child's Health & $\begin{array}{c}-0.030^{* * *} \\
(0.011)\end{array}$ & $\begin{array}{c}-0.023^{* *} \\
(0.012)\end{array}$ \\
\hline Child's Political Identity & $0.283^{* * *}$ & $0.225^{* *}$ \\
\hline (Reference: Non-Communist) & $(0.084)$ & $(0.094)$ \\
\hline Child's Job Type & 0.080 & 0.111 * \\
\hline (Reference: Non-employment) & $(0.069)$ & $(0.066)$ \\
\hline Child's Smoking & $-0.239 * * *$ & -0.191 ** \\
\hline (Reference: Don't smoke) & $(0.092)$ & $(0.089)$ \\
\hline Child's Exercising & $0.216^{* * *}$ & $0.189^{* *}$ \\
\hline (Reference: Don't exercise) & $(0.072)$ & $(0.076)$ \\
\hline Father's Household Registration & $0.441^{* * *}$ & 0.277 * \\
\hline (Reference: Rural) & $(0.150)$ & $(0.154)$ \\
\hline Father's Job Type & $-0.400 * *$ & $-0.415^{* *}$ \\
\hline (Reference: Non-employment) & $(0.176)$ & $(0.162)$ \\
\hline Father's Alcoholism & $0.151^{* *}$ & 0.135 * \\
\hline (Reference: No alcoholism) & $(0.076)$ & $(0.073)$ \\
\hline Transfer & $0.194^{* *}$ & $0.163^{* *}$ \\
\hline (Reference: No transfer income) & $(0.077)$ & $(0.074)$ \\
\hline Fuel & $-0.199 * *$ & -0.095 \\
\hline (Reference: Non clean energy) & $(0.078)$ & $(0.081)$ \\
\hline Size & $\begin{array}{c}0.119 * * * \\
(0.017)\end{array}$ & $\begin{array}{c}0.084^{* * *} \\
(0.022)\end{array}$ \\
\hline Gifting Expenses & $\begin{array}{c}0.040^{* * *} \\
(0.015)\end{array}$ & $\begin{array}{c}0.036^{* *} \\
(0.015)\end{array}$ \\
\hline Constant & $\begin{array}{c}0.349 \\
(0.567)\end{array}$ & $\begin{array}{c}1.705^{* *} \\
(0.868)\end{array}$ \\
\hline Accuracy & 72.49 & 73.62 \\
\hline LR/Wald Chi2 & $421.92 * * *$ & $522.48^{* * *}$ \\
\hline Endog & & $16.26^{* * *}$ \\
\hline $\mathrm{AR}$ & & $10.23 * *$ \\
\hline $\mathrm{N}$ & 1705 & 1687 \\
\hline $\mathrm{R}^{2}$ & 0.185 & \\
\hline
\end{tabular}

Note: Based on CFPS 2018. Standard errors in parentheses under the coefficients. ${ }^{*} p<0.1,{ }^{* *} p<0.05,{ }^{* * *} p<0.01$. Reference group in parentheses under the qualitative variable name. Insignificant variables are omitted.

In addition, a child's education (-0.285), political identity (0.255), job type $(0.11)$, smoking status ( -0.191$)$, and exercising behavior (0.189); a father's household registration (0.277), job type (-0.415), and alcoholism behavior (0.135); and the family's receipt of transfer income (0.163), size (0.084), and gifting expenses (0.036) still have significant impacts on the probability of ITP. A child's age $(-0.032)$ and medical expenditure $(-0.023)$ 
significantly blocked the ITP when the sample size was reduced, possibly because age growth promotes the child's economic accumulation, and increased medical expenditure improves the child's health capital, hence their improved economic acquisition ability.

Overall, in this section, we used alternative samples and found that the participation of children and fathers in SI and other factors have significant impacts on the ITP, hence the conclusions were robust.

\subsubsection{Alternative Method}

In the previous analysis, we used a linear probability model (probit) and an instrumental variable method to analyze the impact of child and father participation in SI on the ITP. In this section, we used a linear regression and 2-stage least square (2SLS) model for alternative analysis to check the robustness of the previous conclusions.

As shown in Column 2 of Table 5, a child's participation in pension insurance $(-0.088)$ and medical insurance (0.06), and a father's participation in pension insurance (0.043) significantly affects the ITP, and the impact direction was still the same as the previous analysis. However, the difference was that a father's participation in medical insurance (0.087) significantly improves the ITP, which may come from the endogeneity, so we payed more attention to the results of the 2SLS model. In Column 3, as shown in the results of the 2SLS model, a child's participation in pension insurance $(-0.335)$ and a father's participation in medical insurance $(-0.97)$ significantly reduce the ITP, while a child's participation in medical insurance (0.474) and a father's participation in pension insurance (0.279) have the opposite significant effect. Other significant variables also have robust effects on the ITP.

Table 5. Alternative method.

\begin{tabular}{|c|c|c|}
\hline \multirow{2}{*}{ Variables } & (1) & (2) \\
\hline & OLS & 2SLS \\
\hline Child's Pension Insurance & $\begin{aligned}- & 0.088^{* * *} \\
& (0.020)\end{aligned}$ & $\begin{array}{c}-0.335^{* *} \\
(0.145)\end{array}$ \\
\hline Child's Medical Insurance & $\begin{array}{c}0.060^{* *} \\
(0.029)\end{array}$ & $\begin{array}{c}0.474^{* *} \\
(0.215)\end{array}$ \\
\hline Father's Pension Insurance & $\begin{array}{l}0.043 * \\
(0.024)\end{array}$ & $\begin{array}{c}0.279 * * \\
(0.124)\end{array}$ \\
\hline Father's Medical Insurance & $\begin{array}{l}0.087 * \\
(0.048)\end{array}$ & $\begin{array}{l}-0.970 * * * \\
(0.364)\end{array}$ \\
\hline Child's Age & $\begin{aligned}-0.014^{* * *} & (0.003)\end{aligned}$ & $\begin{array}{c}-0.009 * \\
(0.005)\end{array}$ \\
\hline Child's Education & $\begin{aligned}- & 0.116^{* * *} \\
& (0.011)\end{aligned}$ & $\begin{array}{l}-0.099 * * * \\
(0.019)\end{array}$ \\
\hline Child's Health & $\begin{array}{l}-0.006^{*} \\
(0.003)\end{array}$ & $\begin{array}{l}-0.004 \\
(0.004)\end{array}$ \\
\hline Child's Social Position & $\begin{array}{c}0.021 * * \\
(0.010)\end{array}$ & $\begin{array}{c}0.017 \\
(0.012)\end{array}$ \\
\hline Child's Political Identity & $0.079^{* * *}$ & $0.073^{* *}$ \\
\hline (Reference: Non-Communist) & $(0.023)$ & $(0.030)$ \\
\hline Child's Job Type & $0.034^{*}$ & $0.048^{* *}$ \\
\hline (Reference: Non-employment) & $(0.020)$ & $(0.024)$ \\
\hline $\begin{array}{c}\text { Child's Smoking } \\
\text { (Reference: Don't smoke) }\end{array}$ & $\begin{array}{c}-0.069^{* * *} \\
(0.025)\end{array}$ & $\begin{array}{l}-0.066^{* *} \\
(0.030)\end{array}$ \\
\hline Child's Exercising & $0.050 * *$ & $0.056^{* *}$ \\
\hline (Reference: Don't exercise) & $(0.021)$ & $(0.024)$ \\
\hline $\begin{array}{c}\text { Father's Household } \\
\text { Registration }\end{array}$ & $0.083^{* *}$ & $0.277 *$ \\
\hline (Reference: Rural) & $(0.038)$ & $(0.154)$ \\
\hline Father's Job Type & $-0.091 *$ & $-0.125^{* *}$ \\
\hline (Reference: Non-employment) & $(0.048)$ & $(0.056)$ \\
\hline
\end{tabular}


Table 5. Cont.

\begin{tabular}{ccc}
\hline Variables & $\mathbf{( 1 )}$ & $\mathbf{( 2 )}$ \\
\cline { 2 - 3 } & OLS & 2SLS \\
\hline Father's Alcoholism & 0.026 & 0.030 \\
(Reference: No alcoholism) & $(0.022)$ & $(0.026)$ \\
Transfer & $0.069^{* * *}$ & $0.075^{* * *}$ \\
(Reference: No transfer & $(0.022)$ & $(0.026)$ \\
income) & $-0.056^{* *}$ & -0.027 \\
Fuel & $(0.023)$ & $(0.028)$ \\
& $0.031^{* * *}$ & $0.023^{* * *}$ \\
Size & $(0.005)$ & $(0.006)$ \\
& $0.012^{* * *}$ & $0.012^{* *}$ \\
Gifting Expenses & $(0.004)$ & $(0.005)$ \\
Constant & 0.680 & $1.170 * *$ \\
& $(0.133)$ & $(0.345)$ \\
$\mathrm{N}$ & 2098 & 2081 \\
$\mathrm{R}^{2}$ & 0.192 & \\
\hline
\end{tabular}

Note: Based on CFPS 2018. Standard errors in parentheses under the coefficients. ${ }^{*} p<0.1,{ }^{* *} p<0.05,{ }^{* * *} p<0.01$. Reference group in parentheses under the qualitative variable name. Insignificant variables are omitted.

Overall, the 2SLS estimation result was the same as the IV-probit result, so the conclusions on the impact of the participation of children and fathers in SI on the ITP were robust.

\subsubsection{Alternative Measure}

So far, we measured the social insurance participation of children and fathers based on the distinction between basic insurance and supplementary insurance, i.e., we defined the participation as variables ranging from 1 to 3 . To avoid analysis bias caused by measurement errors, in this section, we redefined the participation of children and fathers in SI as qualitative variables, 0 (not participating in any insurance) and 1 (participating in at least one insurance), for analysis in order to check the robustness of the conclusions.

As shown in the IV-probit estimation of Table 6, the probability of the ITP for a child participating in medical insurance and a father participating in pension insurance was significantly lower than that of an uninsured group, while the probability of the ITP of a child participating in medical insurance and a father participating in pension insurance was significantly higher than that of an uninsured group, which is similar to the results obtained by the basic regression model. When compared, the coefficients based on participation were higher than those based on what kind of insurance to participate in.

Therefore, the conclusions of the impact of the participation of children and fathers in SI on the ITP in the basic regression model are not only robust, but also more accurate than the measurement method considering participation only.

\subsection{Heterogeneity}

\subsubsection{Household Registration}

China's development can be characterized by the separation of urban and rural areas, and urban areas are far superior in many ways. Furthermore, there is a gap in social insurance policies between urban and rural areas, even though the government is trying to narrow it. In this section, we divided the samples into urban and rural groups according to the child's hukou, with sample sizes of 312 and 1769, respectively.

In the IV-probit model, as shown in Table 7, for the urban groups, a child's effort seems to be more important. Specifically, a child's participation in pension insurance and medical insurance have significant effects on both the probability of the ITP of rural $(-0.795$ and 1.443) and urban (-1.621 and 1.593) residents, but it is stronger for the latter. And only rural residents' participation in medical $(-2.420)$ and pension (0.777) insurance have significant impacts on the probability of the ITP. This accords with the fact that in rural 
areas, as opposed to urban areas, individuals accumulate economic capital slowly, clan culture has a strong influence, and families and neighbors play an important role in social communication and income growth. Thus, the choices of fathers and children will impact the ITP in rural areas.

Table 6. Alternative measure.

\begin{tabular}{|c|c|c|}
\hline \multirow{2}{*}{ Variables } & (1) & (2) \\
\hline & Probit & IV-Probit \\
\hline Child's Pension Insurance & $-0.268^{* * *}$ & $-1.002^{* * *}$ \\
\hline (Reference: No participation) & -0.268 & $(0.319)$ \\
\hline Child's Medical Insurance & $0.179 *$ & $1.187^{* *}$ \\
\hline (Reference: No participation) & 0.179 & $(0.499)$ \\
\hline Father's Pension Insurance & $0.150 *$ & $0.818^{* * *}$ \\
\hline (Reference: No participation) & 0.150 & $(0.285)$ \\
\hline Father's Medical Insurance & $0.343 * *$ & $-2.427^{* * *}$ \\
\hline (Reference: No participation) & 0.343 & $(0.680)$ \\
\hline \multirow[t]{2}{*}{ Child's Age } & $-0.040^{* * *}$ & -0.016 \\
\hline & -0.040 & $(0.013)$ \\
\hline \multirow[t]{2}{*}{ Child's Education } & $-0.373^{* * *}$ & $-0.227^{* * *}$ \\
\hline & -0.373 & $(0.070)$ \\
\hline \multirow[t]{2}{*}{ Child's Health } & $-0.018^{*}$ & -0.007 \\
\hline & -0.018 & $(0.010)$ \\
\hline \multirow[t]{2}{*}{ Child's Social Position } & $0.063^{* *}$ & 0.042 \\
\hline & 0.063 & $(0.029)$ \\
\hline Child's Political Identity & $0.256^{* * *}$ & $0.179 * *$ \\
\hline (Reference: Non-Communist) & 0.256 & $(0.079)$ \\
\hline Child's Job Type & $0.116^{*}$ & $0.119 * *$ \\
\hline (Reference: Non-employment) & 0.116 & $(0.057)$ \\
\hline Child's Smoking & $-0.201^{* *}$ & $-0.143^{* * *}$ \\
\hline (Reference: Don't smoke) & -0.201 & $(0.075)$ \\
\hline Child's Exercising & $0.156^{* *}$ & 0.110 * \\
\hline (Reference: Don't exercise) & 0.156 & $(0.064)$ \\
\hline Father's Household & $0.301^{* *}$ & 0.057 \\
\hline (Reference: Rural) & 0.301 & $(0.130)$ \\
\hline Father's Job Type & $-0.292 *$ & $-0.314^{* *}$ \\
\hline (Reference: Non-employment) & -0.292 & $(0.137)$ \\
\hline Transfer & $0.223^{* * *}$ & $0.195^{* * *}$ \\
\hline (Reference: No transfer & 0.223 & $(0.064)$ \\
\hline \multirow{2}{*}{$\begin{array}{c}\text { Fuel } \\
\text { (Reference: Non clean energy) }\end{array}$} & $-0.168^{* *}$ & -0.057 \\
\hline & -0.168 & $(0.069)$ \\
\hline \multirow[t]{2}{*}{ Size } & $0.097^{* * *}$ & $0.054^{* * *}$ \\
\hline & 0.097 & $(0.019)$ \\
\hline \multirow[t]{2}{*}{ Gifting Expenses } & $0.041^{* * *}$ & $0.029 * *$ \\
\hline & 0.041 & $(0.013)$ \\
\hline \multirow[t]{2}{*}{ Constant } & 0.431 & $1.420 *$ \\
\hline & $(0.420)$ & $(0.814)$ \\
\hline Accuracy & 72.08 & 72.85 \\
\hline LR/Wald Chi2 & $439.10^{* * *}$ & $712.13^{* * *}$ \\
\hline Endog & & $33.08^{* * *}$ \\
\hline AR & & $17.75^{* * *}$ \\
\hline $\mathrm{N}$ & 2099 & 2081 \\
\hline $\mathrm{R}^{2}$ & 0.158 & \\
\hline
\end{tabular}

Note: Based on CFPS 2018. Standard errors in parentheses under the coefficients. ${ }^{*} p<0.1,{ }^{* *} p<0.05,{ }^{* * *} p<0.01$ Reference group in parentheses under the qualitative variable name. Insignificant variables are omitted. 
Table 7. Heterogeneity in household registration.

\begin{tabular}{|c|c|c|}
\hline \multirow{2}{*}{ Variables } & (1) & (2) \\
\hline & Rural & Urban \\
\hline Child's Pension Insurance & $\begin{array}{l}-0.795^{* *} \\
(0.333)\end{array}$ & $\begin{array}{l}-1.621^{* * *} \\
(0.468)\end{array}$ \\
\hline Child's Medical Insurance & $\begin{array}{c}1.443^{* * *} \\
(0.545)\end{array}$ & $\begin{array}{l}1.593^{* *} \\
(0.668)\end{array}$ \\
\hline Father's Pension Insurance & $\begin{array}{c}0.777^{* * *} \\
(0.300)\end{array}$ & $\begin{array}{l}-0.293 \\
(0.682)\end{array}$ \\
\hline Father's Medical Insurance & $\begin{array}{l}-2.420 * * * \\
(0.670)\end{array}$ & $\begin{array}{l}-1.466 \\
(2.042)\end{array}$ \\
\hline Child's Age & $\begin{array}{c}-0.024 * \\
(0.014)\end{array}$ & $\begin{array}{l}0.015 \\
0.035\end{array}$ \\
\hline Child's Education & $\begin{aligned} &-0.228 * * * \\
&(0.072)\end{aligned}$ & $\begin{array}{l}-0.136 \\
0.189\end{array}$ \\
\hline Child's Job Type & $0.133^{* *}$ & -0.024 \\
\hline (Reference: Non-employment) & $(0.063)$ & $(0.618)$ \\
\hline Child's Smoking & $-0.167^{* *}$ & 0.189 \\
\hline (Reference: Don't smoke) & $(0.082)$ & $(0.230)$ \\
\hline Child's Exercising & $0.134^{* *}$ & 0.007 \\
\hline (Reference: Don't exercise) & $(0.068)$ & $(0.199)$ \\
\hline Father's Job Type & $-0.297^{* *}$ & -0.398 \\
\hline (Reference: Non-employment) & $(0.149)$ & $(0.438)$ \\
\hline Father's Reading & 0.008 & $0.448^{* *}$ \\
\hline (Reference: Don't read) & $(0.102)$ & $(0.228)$ \\
\hline Transfer & $0.197^{* * *}$ & 0.065 \\
\hline $\begin{array}{l}\text { (Reference: no transfer } \\
\text { income) }\end{array}$ & $(0.070)$ & $(0.226)$ \\
\hline Size & $\begin{array}{l}0.051 * * \\
(0.022)\end{array}$ & $\begin{array}{c}0.052 \\
(0.043)\end{array}$ \\
\hline Gifting expenses & $\begin{array}{c}0.039 * * * \\
(0.015)\end{array}$ & $\begin{array}{l}-0.006 \\
(0.038)\end{array}$ \\
\hline Constant & $\begin{array}{l}1.110 \\
(0.903)\end{array}$ & $\begin{array}{l}2.285 \\
(2.001)\end{array}$ \\
\hline Accuracy & 71.15 & 81.41 \\
\hline Wald Chi2 & $641.96^{* * *}$ & $253.71 * * *$ \\
\hline Endog & $35.04^{* * *}$ & $23.48^{* * *}$ \\
\hline $\mathrm{AR}$ & $17.66^{* * *}$ & 7.57 \\
\hline $\mathrm{N}$ & 1769 & 312 \\
\hline
\end{tabular}

Note: Based on CFPS 2018. Standard errors in parentheses under the coefficients. ${ }^{*} p<0.1,{ }^{* *} p<0.05,{ }^{* * *} p<0.01$ Reference group in parentheses under the qualitative variable name. Insignificant variables are omitted.

In addition, the child's individual characteristics, such as age, education, job type, smoking status, exercising behavior, their father's job type and family characteristics, such as the receipt of transfer income, size, and gifting expenses, have significant impacts on the ITP only for rural residents. A father's reading behavior only has a significant impact on the ITP of urban residents. This also supports the fact that in urban areas, a father's and family characteristics have less of an impact on the ITP.

\subsubsection{Geographical Location}

Another developmental feature of China's economy and society can be summarized as the separation of the eastern region and other regions. Specifically, the provinces on the eastern coastline have a good geographical location and market environment, and have benefitted from rapid economic development in China. Therefore, there are differences in the implementation and development of SI between the eastern region and other regions, which is also the reason why we analyze the geographical location heterogeneity of the impact of SI on the ITP in this section. Specifically, we defined the samples from Beijing, Tianjin, Hebei, Liaoning, Shanghai, Jiangsu, Zhejiang, Fujian, Shandong, Guangdong, 
Guangxi, and Hainan as the Eastern group, and other samples as the other group, with sample sizes of 729 and 1352, respectively.

As shown in Table 8, a father's participation in pension insurance significantly improved the probability of the ITP for the residents in the East (1.08) and other locations (0.583), which is consistent with the previous analysis but stronger for the former. A child's participation in pension insurance $(-0.89)$ and medical insurance (1.7) only have significant impacts on the probability of the ITP of non-Eastern residents, while a father's participation in medical insurance (-2.242) only has a significant impact on the probability of the ITP of Eastern residents. One possible explanation is that there is a gap between the eastern location and other locations in the cost of living, insurance payments, and treatment, specifically, for children, with the more comprehensive the pension insurance the more likely individuals are to have a higher awareness of risk prevention. In the non-eastern locations with lower costs, individuals are able to deal with risk events and have a lower probability of falling into poverty. And as for medical insurance, individuals with better health benefit less. For fathers in locations with high medical costs, i.e., the Eastern group, the proportion of medical insurance reimbursements is high, which can effectively reduce the rise of the ITP caused by diseases.

Table 8. Heterogeneity in geographical location.

\begin{tabular}{|c|c|c|}
\hline Variables & Eastern & Others \\
\hline Child's Pension Insurance & $\begin{array}{l}-0.780 \\
(0.679)\end{array}$ & $\begin{array}{l}-0.890 * * * \\
(0.310)\end{array}$ \\
\hline Child's Medical Insurance & $\begin{array}{l}-1.361 \\
(0.915)\end{array}$ & $\begin{array}{l}1.700 * * * \\
(0.420)\end{array}$ \\
\hline Father's Pension Insurance & $\begin{array}{l}1.080 * * * \\
(0.377)\end{array}$ & $\begin{array}{l}0.583 * \\
(0.303)\end{array}$ \\
\hline Father's Medical Insurance & $\begin{array}{c}-2.242 * * * \\
(0.770)\end{array}$ & $\begin{array}{l}-1.210 \\
(1.289)\end{array}$ \\
\hline Child's Education & $\begin{array}{c}0.010 \\
(0.158)\end{array}$ & $\begin{array}{c}-0.291 * * * \\
(0.068)\end{array}$ \\
\hline Child's Political Identity & $0.219 * *$ & $0.216^{* *}$ \\
\hline $\begin{array}{l}\text { (Reference: Non-Communist) } \\
\text { Child's Smoking }\end{array}$ & $\begin{array}{l}(0.111) \\
0.126\end{array}$ & $-0.270 * * *$ \\
\hline (Reference: Don't smoke) & $(0.108)$ & $(0.094)$ \\
\hline Child's Exercising & -0.117 & $0.230 * * *$ \\
\hline (Reference: Don't exercise) & $(0.090)$ & $(0.081)$ \\
\hline Father's Marriage & $0.366^{*}$ & -0.007 \\
\hline (Reference: Unmarried) & $(0.222)$ & $(0.185)$ \\
\hline Father's Social position & $\begin{array}{l}-0.085^{* *} \\
(0.038)\end{array}$ & $\begin{array}{c}0.002 \\
(0.034)\end{array}$ \\
\hline Father's Job Type & -0.126 & $-0.279 *$ \\
\hline (Reference: Non-employment) & $(0.253)$ & $(0.167)$ \\
\hline Transfer & 0.085 & $0.211 * *$ \\
\hline (Reference: No transfer income) & $(0.108)$ & $(0.084)$ \\
\hline Fuel & 0.102 & $-0.143 *$ \\
\hline (Reference: Non clean energy) & $(0.122)$ & $(0.086)$ \\
\hline Size & $\begin{array}{c}0.052 * * \\
(0.023)\end{array}$ & $\begin{array}{l}0.053 * * \\
(0.026)\end{array}$ \\
\hline Gifting expenses & $\begin{array}{c}0.022 \\
(0.018)\end{array}$ & $\begin{array}{l}0.040^{* *} \\
(0.018)\end{array}$ \\
\hline Constant & $\begin{array}{c}1.818 \\
(1.243)\end{array}$ & $\begin{array}{c}0.044 \\
(1.362)\end{array}$ \\
\hline Accuracy & 73.66 & 71.82 \\
\hline Wald Chi2 & $874.57 * * *$ & $489.04^{* * *}$ \\
\hline Endog & $113.12^{* * *}$ & $19.05^{* * *}$ \\
\hline $\mathrm{AR}$ & 6.47 & $14.04^{* * *}$ \\
\hline $\mathrm{N}$ & 729 & 1352 \\
\hline
\end{tabular}

Note: Based on CFPS 2018. Standard errors in parentheses under the coefficients. ${ }^{*} p<0.1,{ }^{* *} p<0.05,{ }^{* * *} p<0.01$ Reference group in parentheses under the qualitative variable name. Insignificant variables are omitted.

\subsubsection{Marriage}

The family can be regarded as a consortium that jointly bears the cost of living, and deals with unknown risks. Marriage is the most common way to form a family. In this 
section, according to the marital status of the child, the samples were divided into the unmarried group and married group, with sample sizes of 928 and 1153, respectively.

As shown in Table 9, a father's participation in pension insurance (0.724) only has a significant impact on the children of married families. A child's pension insurance and medical insurance participation, and a father's medical insurance participation have significant impacts on the probability of the ITP, and both the participation of child and father in medical insurance have stronger impacts on the probability of the ITP for the children of married families, while the impact of a child's pension insurance participation is the opposite.

For children, marriage indicates that they have to carry their own living costs, which increases by a greater amount than the reduction from the scale effect. Therefore, although participation in pension insurance still blocks the ITP, it is lower for married families. Meanwhile, medical insurance participation increases life pressure for a married family, so it is stronger. As married children are more likely to provide economic inter-generational support, while unmarried children are more likely to provide caring inter-generational support, participation in medical insurance improves the father's ability to cope with disease risk and further reduces the married children's economic support when their parents were ill, hence enhancing the blocking impact on the ITP.

Overall, there was marital heterogeneity in the impact of social insurance on the ITP.

Table 9. Heterogeneity in marriage.

\begin{tabular}{|c|c|c|}
\hline \multirow{2}{*}{ Variables } & (1) & (2) \\
\hline & Unmarried & Married \\
\hline \multirow[t]{2}{*}{ Child's Pension Insurance } & $-0.901 *$ & $-0.854^{* * *}$ \\
\hline & $(0.517)$ & $(0.317)$ \\
\hline \multirow[t]{2}{*}{ Child's Medical Insurance } & $1.072 *$ & $1.207 *$ \\
\hline & $(0.712)$ & $(0.694)$ \\
\hline \multirow[t]{2}{*}{ Father's Pension Insurance } & 0.819 & $0.724^{* *}$ \\
\hline & $(0.424)$ & $(0.336)$ \\
\hline \multirow[t]{2}{*}{ Father's Medical Insurance } & $-2.193^{* *}$ & $-2.378^{* *}$ \\
\hline & $(0.950)$ & $(0.952)$ \\
\hline \multirow[t]{2}{*}{ Gender } & 0.025 & $-0.256^{*}$ \\
\hline & $(0.111)$ & $(0.137)$ \\
\hline \multirow[t]{2}{*}{ Child's Education } & $-0.215^{*}$ & $-0.225^{* * *}$ \\
\hline & $(0.122)$ & $(0.075)$ \\
\hline Child's Political Identity & 0.283 * & -0.003 \\
\hline (Reference: Non-Communist) & $(0.159)$ & $(0.099)$ \\
\hline \multirow[t]{2}{*}{ Child's Social Position } & -0.014 & 0.073 * \\
\hline & $(0.050)$ & $(0.039)$ \\
\hline Child's Job Type & 0.096 & $0.147 *$ \\
\hline (Reference: Non-employment) & $(0.089)$ & $(0.078)$ \\
\hline Child's Exercising & $0.218^{*}$ & 0.035 \\
\hline (Reference: Don't exercise) & $(0.125)$ & $(0.080)$ \\
\hline Father's Alcoholism & 0.195 * & 0.034 \\
\hline (Reference: No alcoholism) & $(0.103)$ & $(0.083)$ \\
\hline Transfer & 0.164 & $0.177^{* *}$ \\
\hline (Reference: No transfer income) & $(0.114)$ & $(0.085)$ \\
\hline Water & 0.021 & $-0.177^{*}$ \\
\hline (Reference: Non clean water) & $(0.108)$ & $(0.098)$ \\
\hline \multirow[t]{2}{*}{ Size } & $0.086^{* *}$ & 0.033 \\
\hline & $(0.041)$ & $(0.020)$ \\
\hline \multirow[t]{2}{*}{ Gifting expenses } & 0.022 & 0.034 * \\
\hline & $(0.020)$ & $(0.020)$ \\
\hline \multirow[t]{2}{*}{ Constant } & 1.876 & 0.621 \\
\hline & $(1.146)$ & $(1.344)$ \\
\hline Accuracy & 76.08 & 71.99 \\
\hline Wald Chi2 & $441.78^{* * *}$ & $314.34 * * *$ \\
\hline Endog & $12.90 * *$ & $22.67 * * *$ \\
\hline $\mathrm{AR}$ & 6.29 & $11.54 * *$ \\
\hline $\mathrm{N}$ & 928 & 1153 \\
\hline
\end{tabular}

Note: Based on CFPS 2018. Standard errors in parentheses under the coefficients. ${ }^{*} p<0.1,{ }^{* *} p<0.05,{ }^{* * *} p<0.01$ Reference group in parentheses under the qualitative variable name. Insignificant variables are omitted. 


\section{Conclusions and Discussion}

This paper analyzed the impact of social insurance on the inter-generational transmission of poverty using the probit model and the IV-probit model. The following findings may help us to better understand poverty transmission.

Firstly, participation in social insurance has a significant impact on the inter-generational transmission of poverty. Specifically, a child's participation in pension insurance and father's participation in medical insurance significantly reduce the probability of the intergenerational transmission of poverty, while the child's medical insurance participation and father's pension insurance participation increase it. Therefore, overall, it is still necessary to expand insurance coverage, especially the child's participation in pension insurance and the fathers' participation in medical insurance. More importantly, it is necessary to adjust the medical insurance system for young people and the pension insurance system for the elderly. Meanwhile, in order to block the ITP, it is beneficial to improve the profitability of medical and pension insurance funds and reasonably control the cost growth to further realize the sustainable development of the funds.

Secondly, the characteristics of children and families have significant impacts on the inter-generational transmission of poverty. In particular, improving child education significantly reduces the probability of the inter-generational transmission of poverty. The probability of the inter-generational transmission of poverty for Communist Party members is significantly higher than that for the general public. The inter-generational transmission of poverty for residents who smoke and exercise less is significantly lower; thus, it is necessary to promote healthy living habits to block the inter-generational transmission of poverty. Families that receive transfer income have a higher probability of the intergenerational transmission of poverty, and policies should protect the working conditions of the poor, rather than focusing on simple transfer income. The expansion of family size and the growth of gifting expenditure significantly increase the probability of the inter-generational transmission of poverty, and active family culture policies may reduce poverty transmission.

Thirdly, there is heterogeneity in household registration, geographical location, and marriage in the impact of social insurance on the inter-generational transmission of poverty. A father's participation in social insurance has a greater impact on the probability of the ITP for rural, Eastern, and married families, while a child's participation in social insurance has a greater impact on that of the urban, non-Eastern, and unmarried families. As indicated by the results, different social policies are needed in the short term for different groups, and but we should pay more attention to the promotion of policies to narrow the gap between urban and rural, eastern and non-eastern, and married and unmarried families in the long term. In addition, family characteristics have significant impacts on the ITP. Therefore, in the future, it would be beneficial to promote the current individual social insurance to a family insurance to better block the impact of social insurance on the ITP. At last, to block the ITP, it is important to implement the inheritance of individual pension insurance and form family mutual help systems for medical insurance, and strengthen individual security, especially access to learning opportunities.

There remain unresolved problems in this direction. This paper focused on the impact of social insurance on the inter-generational transmission of poverty, and further work is required to find and understand the mechanisms. For example, the data in this paper meet the basic conditions for causal analysis of cross-sectional data, such as stability, no selective population, and the correction for reverse causality and temporal directionality by applying instrumental variables, but further causal inference is necessary by using panel or time series data in the future.

Author Contributions: Conceptualization, X.D. and N.G.; methodology, X.D.; validation, N.G.; formal analysis, N.G.; investigation, X.D. and N.G.; writing-original draft preparation, N.G.; writingreview and editing, X.D.; supervision, X.D.; project administration, X.D.; funding acquisition, X.D. All authors have read and agreed to the published version of the manuscript. 
Funding: This work was supported in part by the Humanities and Social Science Research Fund of the Ministry of Education in China (grant number: 18YJA790018), and in part by the Fundamental Research Funds of the Central Universities (grant number: CCNU19TS047) to X.D.

Institutional Review Board Statement: Ethical review and approval were waived for this study due to publically open data from the China Family Panel Survey.

Informed Consent Statement: Patient consent was waived due to publically open data from the China Family Panel Survey.

Data Availability Statement: Data used in this paper can be found from the China Family Panel Survey, http:/ / www.isss.pku.edu.cn/cfps/.

Conflicts of Interest: The authors declare no conflict of interest.

\section{Appendix A}

Collinearity between variables may increase the regression error, so this paper carried out a collinearity test before the regression analysis. Tolerance and VIF values are the usual measures of collinearity. In general, the value of tolerance is between 0 and 1 . The smaller the tolerance is, the larger the VIF value is, and the more obvious the collinearity is. When the VIF value is less than 10, there is no obvious collinearity in the regression model.

As shown in Table A1, child age and father age had the highest VIF values at 3.44 and 2.52, respectively, but these were still far less than the general standard of 10 . The VIF value of a fathers' job type was the smallest at 1.02. Accordingly, the minimum tolerance of all variables was 0.291 , and the maximum was 0.977 . Thus, there was no collinearity in this model.

Table A1. Collinearity test.

\begin{tabular}{|c|c|c|}
\hline Variables & VIF & Tolerance \\
\hline Child's Pension Insurance & 1.290 & 0.776 \\
\hline Child's Medical Insurance & 1.140 & 0.874 \\
\hline Father's Pension Insurance & 1.100 & 0.906 \\
\hline Father's Medical Insurance & 1.100 & 0.911 \\
\hline Gender & 1.700 & 0.589 \\
\hline Child's Age & 3.440 & 0.291 \\
\hline Child's Marriage & 1.800 & 0.555 \\
\hline Child's Household Registration & 1.760 & 0.569 \\
\hline Child's Education & 1.710 & 0.583 \\
\hline Child's Health & 1.060 & 0.946 \\
\hline Child's Social Position & 1.040 & 0.957 \\
\hline Child's Political Identity & 1.380 & 0.726 \\
\hline Child's Job Type & 1.030 & 0.975 \\
\hline Child's Location & 1.170 & 0.857 \\
\hline Child's Smoking & 1.740 & 0.576 \\
\hline Child's Alcoholism & 1.170 & 0.856 \\
\hline Child's Reading & 1.210 & 0.829 \\
\hline Child's Exercising & 1.150 & 0.871 \\
\hline Father's Age & 2.520 & 0.396 \\
\hline Father's Marriage & 1.030 & 0.967 \\
\hline Father's Household Registration & 1.640 & 0.610 \\
\hline Father's Education & 1.280 & 0.780 \\
\hline Father's Health & 1.090 & 0.920 \\
\hline Father's Social Position & 1.050 & 0.950 \\
\hline Father's Politic Identity & 1.080 & 0.922 \\
\hline Father's Job Type & 1.020 & 0.977 \\
\hline Father's Smoking & 1.040 & 0.965 \\
\hline Father's Alcoholism & 1.070 & 0.934 \\
\hline Father's Reading & 1.110 & 0.899 \\
\hline Father's Exercising & 1.100 & 0.908 \\
\hline Transfer & 1.230 & 0.815 \\
\hline
\end{tabular}


Table A1. Cont.

\begin{tabular}{ccc}
\hline Variables & VIF & Tolerance \\
\hline Water & 1.140 & 0.881 \\
Fuel & 1.330 & 0.752 \\
Size & 1.330 & 0.752 \\
Gifting expenses & 1.090 & 0.917 \\
Mean & 1.347 & 0.800 \\
\hline
\end{tabular}

Note: Based on CFPS 2018.

\section{References}

1. Banerjee, A.; Duflo, E. How poverty ends: The many paths to progress-and why they might not continue. Foreign Aff. 2020, 99, 22-29.

2. Lybbert, T.; Wydick, B. Poverty, aspirations, and the economics of hope. Econ. Dev. Cult. Chang. 2018, 66, 709-753. [CrossRef]

3. Lin, X.; Li, T. How Can Humble Families Nurture Respected Sons? On the Role of Education in Obstructing Intergenerational Transmission of Poverty. J. Jiangxi Univ. Financ. Econ. 2019, 125, 12-23.

4. Jiao, K.; Chen, C. Research on the influence mechanism of social capital on intergenerational transmission of rural poverty. China's Popul. Resour. Environ. 2020, 30, 169-179.

5. Yan, H.; Yang, S. The relative poverty governance effect of rural medical security system: Evidence from the perspective of poverty vulnerability. J. Hunan Agric. Univ. (Soc. Sci. Ed.) 2021, 22, 48-55.

6. Liu, E.; Zhang, Q. Effect Evaluation of Social Endowment Insurance on Alleviating Elderly Poverty in Rural China-An Empirical Analysis Based on the Data CLHLS (2011). Agric. Technol. Econ. 2018, 1, 98-110.

7. Henao-Cespedes, V.; Gómez, Y.A.G.; Ruggeri, S.; Henao-Cespedes, T.-M. Relationship analysis between the spread of COVID-19 and the multidimensional poverty index in the city of Manizales, Colombia. Egypt. J. Remote Sens. Space Sci. 2021. [CrossRef]

8. Lesner, R.V. The long-term effect of childhood poverty. J. Popul. Econ. 2018, 31, 969-1004. [CrossRef]

9. Li, X. Review of intergenerational transmission theory of poverty. J. Guangxi Young Cadres Coll. 2006, 2, 75-78, 84. (In Chinese)

10. Zhang, L. Empirical Study on the Intergenerational Transmission of Poverty in Rural China. China Popul. Resour. Environ. 2013, 23, 45-50.

11. Solon, G. Inter-generational income mobility in the United States. Am. Econ. Rev. 1992, 3, 393-408.

12. Zhao, H.; Gao, P. The impact of children's education on the intergenerational transmission of rural poverty in China-An Empirical Analysis Based on chip2013. Educ. Res. Mon. 2017, 12, 26-32.

13. Ge, L.; Wu, Y. Has Urbanization Blocked the Intergenerational Transmission of Poverty?-Evidence from CFPS2018. Beijing Soc. Sci. 2020, 211, 14-27.

14. Zhou, X.; Wang, F. A Comparative Study of the Intergenerational Income Mobility between the Urban and Rural China. Popul. J. 2014, 36, 64-73.

15. Liu, X.; Wen, J.; Liu, Y. Research progress on intergenerational transmission of poverty. Econ. Trends 2019, 8, 130-147.

16. Duan, Y. Inter-generational transmission of education and rural relative poverty-A test based on instrumental variable method. Rural Econ. 2020, 9, 67-75.

17. Wu, X.; Guo, S.; Liu, C.; Chen, L.; Guo, Y. The Emphasis of Fatherhood in Social Change: Analysis Based on Bronfenbrenner's Ecological Systems Theory. J. South China Norm. Univ. (Soc. Sci. Ed.) 2012, 6, 56-62, 158.

18. Atkinson, A.; Trinder, C.; Maynard, A.; Corlyon, J.; Jenkins, S.P.; Sutherland, H. Parents and Children: Incomes in Two Generations. Lond. Eng. 1983, 20, 3325-3331.

19. Hertz, T.N. Education, Inequality and Economic Mobility in South Africa; Doctoral Dissertations Available from Proquest. 2001. Available online: https:/ / scholarworks.umass.edu/dissertations / AAI3027205 (accessed on 8 December 2021).

20. Cardak, B.A.; Johnston, D.W.; Martin, V.L. Intergenerational earnings mobility: A new decomposition of investment and endowment effects. Labour Econ. 2013, 24, 39-47. [CrossRef]

21. Xie, E. Mediation of Education Effects on Intergenerational Transmission of Poverty. Econ. Sci. 2021, 1, $134-144$.

22. Fan, C.; Chen, D. Decreasing Poverty and Increasing Income Effect of New Rural Social Endowment Insurance-Based on the Empirical Test of "China Health and Retirement Longitudinal Study". Qiushi 2014, 41, 62-70.

23. Qin, X.Z.; Wang, T.Y.; Zhuang, C. Intergenerational transfer of human capital and its impact on income mobility: Evidence from China. China Econ. Rev. 2016, 38, 306-321. [CrossRef]

24. World Bank. Poverty and Shared Prosperity 2018: Piecing Together Poverty Puzzle. 2018. Available online: https://www. worldbank.org/en/publication/poverty-and-sharedprosperity (accessed on 12 November 2019).

25. Campbell, J.C.; Dahrendorf, R. Life Chances: Approaches to Social and Political Theory. Foreign Aff. 1980, 58, 970. [CrossRef]

26. Huang, H. Empirical Study on Intergenerational Transmission of Poverty in China; Jinan University: Jinan, China, 2017.

27. Chen, Z.; Shen, Y.; Zhou, Y. On the Absolute and Relative Changes in the Poverty in China's Villages and on the Setting of the Relative Poverty Line. Manag. World 2013, 1, 67-77, 187-188.

28. Bian, S.; Song, J.; Sun, Y. An Analysis of the Effect of Pension for Urban and Rural Residents on Alleviating Old Age Poverty in China: From the Perspective of Absolute Poverty and Relative Poverty. J. Liaoning Univ. (Philos. Soc. Sci. Ed.) 2020, 48, 88-97. 
29. Cai, S. Research on the current situation and Countermeasures of inter-generational transmission of rural poverty in Northwest China-Based on the investigation of deep poverty villages in Gansu. J. North Univ. Natl. (Philos. Soc. Sci. Ed.) 2019, 3, 34-38.

30. Su, Y.; Xu, F. Reaserch on Inter-generational Income Transmission Mechanism and the Way to Solve Poverty. Stat. Inf. Forum 2021, $36,95-105$.

31. Chen, J.; Zhan, P.; Wei, Y. The Intergenerational Transmission of Relative Poverty in Rural China: Analysis Based on Different Cohorts. Soc. Sci. Nanjing 2021, 6, 39-47.

32. Harper, C.; Marcus, R.; Moore, K. Enduring Poverty and the Conditions of Childhood: Lifecourse and Intergenerational Poverty Transmissions. World Dev. 2003, 31, 535-554. [CrossRef]

33. Nam, J. Government spending during childhood and intergenerational income mobility in the United States. Child. Youth Serv. Rev. 2019, 100, 332-343. [CrossRef]

34. Gou, L.; Liu, R. The Mechanism of Education Supply Blocking the Intergenerational Transmission of Poverty and Its Realization Path. J. Northwest Univ. Agric. For. Sci. Technol. (Soc. Sci. Ed.) 2021, 21, 48-53.

35. Zhang, Y.; Cheng, L.; Liu, Z. Does China's New Rural Pension Scheme Improve the Life Quality of the Rural Elderly? Econ. Res. J. 2013, 48, 42-54. (In Chinese)

36. Qiu, Y.; Zhang, Z. Research on anti poverty of medical security in Guizhou minority areas. J. Chin. Acad. Gov. 2016, 3, 69-75. (In Chinese)

37. Liu, Y.; Wang, R. Exacerbate or Ease? Social Security Transfer Payment and Elderly Poverty-The Analysis Based on the Perspective of Urban and Rural Difference. J. Shanxi Univ. Financ. Econ. 2017, 2, 12-21.

38. Gao, X.; Wang, S.; Yang, H. Gender Differences of the Effects of Pensions on the Alleviation of Old-Age Poverty in Rural Areas. Financ. Econ. Res. 2018, 33, 119-130.

39. Liu, R.; Liu, Q. The Ageing of Population, Old-age Poverty and Security: Based on the Data and Experience of Germany. Popul. Econ. 2016, 2, 104-114.

40. Cheng, L.; Zhang, Y.; Liu, Z. Does the New Rural Pension Scheme Remold the Elder Care Patterns in Rural China? Econ. Res. J. 2013, 8, 42-54. (In Chinese)

41. Xie, E. Pensions and Multidimensional Elderly Poverty and Inequality: A Comparative Perspective on Urban and Rural Non-compulsory Pension Insurance. Chin. J. Popul. Sci. 2017, 5, 64-75, 129.

42. Huang, X.; Li, Y. Empirical analysis on the impact of new rural cooperative medical system on Farmers' medical burden and health level. Agric. Technol. Econ. 2016, 4, 51-58. (In Chinese)

43. Tao, J.; Jin, H. Anti poverty effect and improvement strategy of new rural cooperative medical system-An Empirical Study Based on Jiangxi Province Zhongzhou Acad. J. 2017, 7, 67-72. (In Chinese).

44. Bao, Z.; Zhao, Y. A Study of the Poverty Alleviation Effect of Rural Residents' Medical Insurance: An Empirical Analysis Based on PSM. J. Jiangxi Univ. Financ. Econ. 2018, 1, 90-105.

45. Kim, J.; Frank-Miller, E. Poverty, health insurance status, and health service utilization among the elderly. J. Poverty 2015, 19, 424-444. [CrossRef]

46. Chen, H.; Zeng, H.; Yang, L. Does the New Rural Cooperative Medical Scheme Have Alleviated the Poverty of Rural Residents? Sci. Decis. Mak. 2017, 10, 1-21.

47. Shen, Z. Research on the Impact of New Rural Cooperative Medical System on Labor Supply and Poverty Alleviation; China Agricultural University: Beijing, China, 2017. 